\title{
PENINGKATKAN KEPUASAN KERJA PERAWAT MELALUI KEBIJAKAN DAN MOTIVASI
}

\author{
Endang Purwaningsih*, Krisna Yetti**, Dian Ayubi****
}

\begin{abstract}
Abstrak
Kebijakan, supervisi dan motivasi adalah sebagian dari faktor yang mempengaruhi kepuasan kerja perawat. Penelitian ini menggunakan desain cross sectional untuk mengetahui hubungan kebijakan, supervisi, dan motivasi dengan kepuasan kerja perawat pelaksana di salah satu rumah sakit di Jawa Timur. Penentuan sampel yaitu total populasi sejumlah 146 perawat. Berdasarkan hasil uji univariat didapatkan sebagian besar perawat mempunyai persepsi tidak baik tentang kebijakan, supervisi, dan mempunyai persepsi baik tentang motivasi, dan puas dalam pekerjaannya. Hasil regresi logistik didapatkan motivasi merupakan variabel yang paling berhubungan dengan kepuasan kerja perawat $(\mathrm{OR} 11,688 ; \mathrm{p}=0,000)$. Hal ini menunjukkan bahwa perawat yang mendapat motivasi akan puas 12 kali dibandingkan perawat yang tidak mendapatkan motivasi oleh manajer keperawatan, sedangkan kebijakan merupakan variabel kedua yang berhungan dengan kepuasan kerja (OR 2,436;p=0,017). Peneliti menyimpulkan bahwa motivasi dan kebijakan merupakan variabel yang dapat menjelaskan kepuasan kerja. Berdasarkan hasil penelitian disarankan untuk melakukan evaluasi terhadap kebijakan yang telah ditetapkan secara periodik dan ada sosialisasi apabila ada kebijakan baru.
\end{abstract}

Kata kunci: kebijakan, supervisi, motivasi, kepuasan kerja

\begin{abstract}
Regulation, supervision system, and motivation are several factors which affected nurse's satisfaction. This study used cross sectional design to identify the relationship between regulation, supervision system, and motivation with the work satisfaction of the associate nurse at one of the hospitals in East Java. The sample taken was the total population of was 146 nurses. Based on univariate analysis, it was known that most of the nurses had positive perception toward the regulation, supervision system, and motivation; more over they were also satisfied with their work. The regression logistic result showed that motivation was the most related variable with the work satisfaction of the nurses (OR 11.688 ; $p=0.000)$. This condition showed that the nurse who got motivation to work would gain 12 times of satisfaction level compared with the nurse who was not motivated by the nurse manager. Meanwhile, regulation was the second highlyrelated variable with the work satisfaction (OR 2.436; $p=0.017)$. The researcher concluded that motivation and regulation were the variables which could explain the work satisfaction. Based on this research, it was recommended to conduct the evaluation toward the current regulation periodically and socialize for the new regulation.
\end{abstract}

Key words: regulation, supervision, motivation, work satisfaction

\section{PENDAHULUAN}

Perawat di rumah sakit rata- rata melakukan 93 tugas yang berbeda dalam kurun waktu seminggu. Tugas ini delapan kali lebih rumit daripada pekerja pabrik (Murphy, 1992 dalam Hansten dan Washburn, 2001).

Pelayanan keperawatan yang diberikan oleh perawat sangat kompleks, dan sumber daya manusia keperawatan merupakan sumber daya kesehatan terbesar di rumah sakit yaitu sekitar 5060 persen dari seluruh tenaga kesehatan dan berkonstribusi 60 persen dari jumlah pelayanan kesehatan yang ada di rumah sakit (Gillies, 1994). Selain itu, posisi dan peran perawat sangat vital dan strategis karena perawat menjadi ujung tombak dan tulang punggung pelayanan sebuah rumah sakit (Wardhono, 2004).

Kompleksitas permasalahan, posisi, dan peran perawat yang strategis serta tuntutan pelayanan keperawatan yang bermutu di rumah sakit memerlukan pengelolaan yang optimal melalui suatu manajemen. Keberhasilan organisasi atau perusahaan tidak hanya bagaimana suatu strategi diterapkan tetapi salah satunya juga ditentukan manajemen yang ada dalam organisasi, karena manajemen di dalamnya terdapat tiga ketrampilan yaitu keterampilan teknis, keterampilan manusiawi dan keterampilan konseptual (Robbins, 2003). 
Keterampilan manusiawi yaitu kemampuan seorang manajer dalam mengelola sumber daya manusia keperawatan di rumah sakit, sehingga kualitas kehidupan perawat menjadi baik.

Hasil akhir dari kualitas kehidupan kerja perawat dapat dilihat dari sudut klien, perawat dan sistem (CHSRF, 2001 dalam Maridi 2006). Hasil kualitas yang dimaksud akan tampak dalam kualitas dalam pemberian pelayanan keperawatan, kinerja perawat, kepuasan pasien dan kepuasan kerja perawat. Survei atau penelitian tentang kepuasan kerja karyawan sangat bermanfaat bagi perusahaan maupun karyawan. Kajian tentang kepuasan kerja menjadi telaah penting mengingat adanya perubahan dan perkembangan yang terus-menerus tentang apa yang membuat karyawan puas terhadap pekerjaannya (Debora, 2007)

Pengukuran kepuasan kerja seorang karyawan sangat sulit, karena sifatnya subyektif dan terus berkembang sesuai tuntutan kehidupan. Setiap karyawan mempunyai ukuran secara pribadi untuk mengukur kepuasan kerjanya. Selain itu banyak faktor yang mempengaruhi kepuasan kerja karyawan yaitu kesesuaian pekerjaan, lingkungan kerja, kesempatan berkembang dan kebijakan organisasi (Siregar, 2006)

Kebijakan pelayanan keperawatan berfungsi untuk standarisasi, petunjuk dari manajemen puncak ke tingkat bawah, dan juga berfungsi menyampaikan dan mempercepat pembuatan beberapa keputusan. Salah satu area yang seringkali dilindungi oleh kebijakan adalah kebijakan personel yang tergantung pada tujuan dari program tindakan yang disetujui untuk mempertahankan praktik pekerjaan yang sama dalam upaya kerja yang efisien dan produktif(Swansburg, 1995). Faktor kepuasan kerja yang berpengaruh positif terhadap kualifikasi dari kinerja adalah promosi, hubungan dengan atasan, kondisi kerja dan imbalan jasa (Nilvia, 2006).

Kepuasan kerja staf dapat di lihat dari terpenuhinya kebutuhan fisik dan psikis, di mana kebutuhan psikis tersebut dapat terpenuhinya melalui peran manajer dalam memperlakukan stafnya (Nursalam, 2002). Pengarahan adalah tindakan fisik dan psikis dari manajer keperawatan. Elemen dalam pengarahan adalah motivasi, kepemimpinan, komunikasi, dan pendelegasian (Marquis \& Houston, 2003).
Staf keperawatan harus bertanggung jawab dalam memberikan bantuan kepada klien, pendelegasian yang tepat, kejelasan komunikasi, kemampuan monitoring dan supervisi (Ellis \& Hartley, 2000)

Dalam keperawatan, supevisi menunjukkan kualitas manajer keperawatan dalam menyelesaikan aktivitas dan tugas keperawatan dengan pengaturan awal dan di lihat secara periodik dari kegiatan dan tugas keperawatan yang telah diselesaikan (Huber, 2000). Supervisi bertujuan untuk memberikan bantuan langsung kepada bawahan sehingga dapat melaksanakan tugas atau pekerjaannya dengan baik (Azwar, 1996)

Seiring dengan pelaksanaan supervisi, maka diperlukan motivasi yang berasal dari manajer keperawatan. Manajer memegang peranan penting dalam memotivasi staf untuk mencapai tujuan organisasi(Nursalam, 2002). Motivasi kerja memang dibutuhkan oleh setiap organisasi demi mencapai tujuannya (Asnawi, 2000).

Kebijakan imbalan jasa sudah di tetapkan oleh direktur salah satu RS di Jawa Timur, namun seiring dengan fluktuasi jumlah pasien, ditemukan perbedaan jumlah imbalan jasa pada setiap ruang. Adanya asumsi dari perawat, bahwa mereka bekerja dengan waktu yang sama, hanya faktor jumlah pasien, ragamnya jenis tindakan dan klasifikasi pasien berdasarkan kelas, menyebabkan mereka mendapat imbalan yang berbeda.

Kejadian yang sempat terlaporkan ke Badan Kepegawaian Daerah(BKD) Kabupaten ini adalah ketidakpuasan perawat dalam sistem rotasi pekerjaan dan perpindahan tempat kerja. Dalam arti ada perawat yang sebelumnya menduduki jabatan fungsional kemudian di pindah ke jabatan struktural atau, dari satu ruangan ke ruangan lain dalam lingkup rumah sakit ini. Masalah rotasi ini sempat menjadi berita hangat di Kabupaten ini, karena perawat merasa diberlakukan tidak adil sehingga tidak puas terhadap sistem rotasi yang diterapkan.

Jumlah tenaga perawat pelaksana di ruang rawat inap, kamar operasi dan UGD di salah satu rumah sakit di Jawa Timur sebanyak 152 orang. Kualifikasi pendidikan perawat yaitu 2 orang Sarjana Keperawatan, 134 orang D III dan 16 perawat lulusan SPK. 
Dari data ini tergambar bahwa masih terdapat perawat lulusan SPK, padahal hasil lokakarya nasional tahun 1985 dijelaskan bahwa pendidikan perawat minimal DIII Keperawatan. Perawat pelaksana yang mempunyai pendidikan S1 Keperawatan masih 2 orang, dan RS tersebut belum pernah membiayai perawat untuk melanjutkan pendidikan ke jenjang S1 Keperawatan.

Kegiatan supervisi di RS ini dalam proses pengembangan yang diharapkan dapat meningkatkan mutu pelayanan keperawatan di rumah sakit. Sejalan dengan proses pengembangan supervisi, maka masalah motivasi perlu juga di identifikasi agar dapat tergambar tentang motivasi perawat yang dapat berdampak pada kepuasan kerja. Penilaian atau survei terhadap kepuasan kerja perawat di RS tersebut belum pernah dilakukan, sehingga manajer keperawatan belum pernah mengetahui bagaimana kepuasan kerja perawat.

Pengukuran kepuasan kerja seorang karyawan sangat sulit, karena sifatnya subyektif dan terus berkembang sesuai tuntutan kehidupan. Setiap karyawan mempunyai ukuran secara pribadi untuk mengukur kepuasan kerjanya. Selain itu banyak faktor yang mempengaruhi kepuasan kerja karyawan yaitu kesesuaian pekerjaan, lingkungan kerja, kesempatan berkembang dan kebijakan organisasi.

Di samping adanya kejelasan dalam melaksanakan segala aktivitas, maka perawat juga membutuhkan pengarahan dalam bentuk supervisi. Seiring dengan pelaksanaan pelayanan tentunya akan ditemukan berbagai masalah yang tidak dapat diselesaikan sendirioleh perawat pelaksana, sehingga perlu bantuan supervisi untuk memecahkan berbagai masalah dalam pelayanan keperawatan.

Adanya kompleksitas permasalahan keperawatan di tatanan pelayanan rumah sakit, maka perawat pelaksana membutuhkan motivasi. Manajer keperawatan harus mampu memberikan motivasi kepada perawat pelaksana. Kegiatan ini perlu dilakukan agar tumbuh suatu kohesivitas kelompok. Motivasi dapat diberikan dalam setiap pertemuan dengan perawat pelaksana.

Tinjauan literatur yang terpaparkan pada latar belakang, memberikan fakta bahwa kebijakan pelayanan keperawatan memberikan kepuasan kerja perawat yang akhirnya akan meningkatkan produktivitas kerja, sehingga kualitas pelayanan keperawatan akan meningkat. Di samping itu sejalan dengan kebijakan yang diterapkan dalam sebuah tatanan pelayanan keperawatan di rumah sakit, maka dibutuhkan supervisi, dan motivasi. Kebijakan, supervisi dan motivasi merupakan suatu kegiatan yang harus dilakukan oleh manajer keperawatan dan hal ini akan berdampak kepada perawat pelaksana.

Manajer keperawatan di rumah sakit perlu mengetahui tentang respon kebijakan, supervisi, dan motivasi yang diterapkan di salah satu Rumah Sakit Umum Daerah di Jawa Timur terhadap kepuasan kerja perawat pelaksana, maka perlu dilakukan penelitian. Hasil dari penelitian akan dapat digunakan sebagai bahan kajian dalam pengambilan keputusan yang berkaitan langsung dengan perawat pelaksana.

Adapun pertanyaan penelitian ini adalah "Bagaimana hubungan antara kebijakan, supervisi, dan motivasi dengan kepuasan kerja perawat pelaksana di salah satu rumah sakit di Jawa Timur?'

\section{METODE}

Penelitian ini merupakan penelitian deskriptif dengan rancangan cross sectional untuk menganalisis hubungan variabel bebas (independent) yaitu kebijakan (imbalan jasa, pengembangan staf dan rotasi), supervisi, dan motivasi. Variabel terikat (dependent) dalam penelitian ini adalah kepuasan kerja perawat pelaksana di salah satu rumah sakit umum daerah di Jawa Timur. Instrumen yang digunakan dalam penelitian adalah kuesioner tentang kebijakan, supervisi, motivasi, dan kepuasan kerja perawat pelaksana. Data yang diperoleh adalah data primer yang berasal daripengisian kuesioner oleh perawat pelaksana. Data yang telah terkumpul dianalisis secara univariat, bivariat dan multivariat dengan aplikasi statistik menggunakan komputer.

\section{HASIL}

Penelitian ini dilaksanakan di ruang rawat inap, UGD, dan kamar operasi dan salah satu RSUD di Jawa Timur pada Juni 2007.

\section{Kebijakan}

Hasil penelitian tentang kebijakan meliputi imbalan jasa, pengembangan staf dan rotasi. 
Tabel 5.2

Distribusi responden berdasarkan kebijakan (imbalan jasa, pengembangan staf, rotasi) di salah satu RSUD di Jawa Timur, Juni 2007 (n=146)

\begin{tabular}{lcc}
\hline \multicolumn{1}{c}{ Sub Variabel } & Frekuensi & $\begin{array}{c}\text { Persentase } \\
(\%)\end{array}$ \\
\hline Imbalan Jasa & & \\
- Tidak Baik & 69 & 47,3 \\
- Baik & 77 & 52,7 \\
Pengembangan staf & & \\
- Tidak Baik & 54 & 37,0 \\
- Baik & 63 & 63,0 \\
Rotasi & & \\
- Tidak Baik & 82 & 56,2 \\
- Baik & 64 & 43,8 \\
\hline
\end{tabular}

Kebijakan imbalan jasa dan pengembangan staf sebagain besar dipersepsi baik oleh perawat, sedangkan tentang rotasi didapatkan sebagian besar perawat mempunyai persepsi tidak baik. Secara keseluruhan hasil penelitian tentang kebijakan (imbalan jasa, pengembangan staf, rotasi) didapatkan perawat sebagian besar $(54,8 \%)$ mempunyai persepsi tidak baik dan hampir setengahnya $(44,2 \%)$ mempunyai persepsi baik. Hasil persepsi responden tentang kebijakan secara keseluruhan dapat dilihat pada tabel 5.3.

Tabel 5.3

Distribusi responden berdasarkan kebijakan di salah satu RSUD di Jawa Timur, Juni 2007 (n=146)

\begin{tabular}{lcc}
\hline V ariabel & Frekuensi & $\begin{array}{c}\text { Persentase } \\
(\boldsymbol{\%})\end{array}$ \\
\hline Kebijakan & & \\
- Tidak baik & 80 & 54,8 \\
- Baik & 66 & 44,2 \\
\hline Jumlah & 146 & 100 \\
\hline
\end{tabular}

\section{Supervisi}

Hasil persepsi responden tentang supervisi dapat dilihat pada tabel 5.5.

Tabel 5.5

Distribusi responden berdasarkan supervisi di salah satu RSUD di Jawa Timur, 2007 (n=146)

\begin{tabular}{lcc}
\hline Variabel & Frekuensi & Persentase(\%) \\
\hline Supervisi & & \\
- Tidak Baik & 76 & 52,1 \\
- Baik & 70 & 47,9 \\
\hline Jumlah & 146 & 100 \\
\hline
\end{tabular}

Persepsi perawat pelaksana mengenai supervisi menunjukkan sebagian besar $(52,1 \%)$ responden mempunyai persepsi tidak baik, dan $47,9 \%$ responden mempunyai persepsi yang baik tentang supervisi.

\section{Motivasi}

Berdasarkan tabel 5.7 terlihat, bahwa persepsi perawat pelaksana mengenai motivasi yang diberikan oleh manajer keperawatan (kepala ruang dan kasi keperawatan) menunjukkan bahwa sebagian besar $(55,5 \%)$ responden mempunyai persepsi baik.

Tabel 5.7

Distribusi responden berdasarkan motivasi di salah satu RSUD di Jawa Timur, Juni 2007 (n=146)

\begin{tabular}{lcc}
\hline Variabel & Frekuensi & $\begin{array}{c}\text { Persentase } \\
(\%)\end{array}$ \\
\hline Motivasi & & \\
- Tidak B aik & 65 & 44,5 \\
- Baik & 81 & 55,5 \\
\hline Jumlah & 146 & 100 \\
\hline
\end{tabular}

\section{Kepuasan kerja perawat pelaksana}

Data tabel 5.9 diatas tentang kepuasan kerja perawat pelaksana di RSUD Dr. Harjono Soedigdomarto,Sp.OG Ponorogo, Jawa Timur menunjukkan menunjukkan sebagian besar $(54,8 \%)$ responden mempunyai perasaan puas dan $42,5 \%$ perawat menyatakan tidak puas.

Tabel 5.9

Distribusi responden berdasarkan kepuasan kerja perawat pelaksana di salah satu RSUD di Jawa Timur, Juni 2007 (n=146)

\begin{tabular}{lcc}
\hline Variabel & Frekuensi & Persentase (\%) \\
\hline Kepuasan Ker ja & & \\
- Tidak Puas & 66 & 45,2 \\
- Puas & 80 & 54,8 \\
\hline Jumlah & 146 & 100 \\
\hline
\end{tabular}

\section{Analisis hubungan variabel independen dengan variabel dependen}

Tabel 5.10

Hasil analisis bivariat variabel kebijakan, supervisi, dan motivasi dengan kepuasan kerja perawat di salah satu RSUD di Jawa Timur, Juni 2007 (n=146)

\begin{tabular}{lccccc}
\hline Variabel & B & S.E & df & Sig. & $\operatorname{Exp(B)}$ \\
\hline Kebijakan & 1.013 & 0.347 & 1 & 0.004 & 2.755 \\
Supervisi & 0.862 & 0.342 & 1 & 0.012 & 2.368 \\
Motivasi & 2.552 & 0.644 & 1 & 0.000 & 12.833 \\
\hline
\end{tabular}

Hubungan antara variabel independen yaitu: kebijakan (imbalan jasa, pengembangan staf, dan rotasi), supervisi, dan motivasi dengan variabel dependen yaitu kepuasan kerja perawat pelaksana, maka dilakukan analisis bivariat dengan tahapan seleksi bivariat menggunakan regresi logistik. 
Hasil analisis bivariat didapatkan $p$-value variabel kebijakan 0,004, supervisi 0,012, dan $p$ value motivasi 0,000 . Hal ini menunjukkan bahwa semua variabel independen berhubungan dengan variabel dependent.

\section{Prediksi varibel independen yang paling berhubungan dengan variabel dependen}

Berdasarkan tabel 5.12, didapatkan bahwa setelah variabel supervisi dikeluarkan, nilai p untuk variabel kebijakan adalah 0,017 dan variabel motivasi 0,000. Kedua variabel tersebut mempunyai nilai $p$ kurang dari 0,05, hal ini berarti variabel kebijakan dan motivasi sebagai prediktor variabel kepuasan kerja perawat pelaksana.

Hasil analisis didapatkan Odds Rotio (OR) yang merupakan $\exp (\mathrm{B})$, dari variabel motivasi adalah 11,688 artinya perawat pelaksana yang mendapatkan motivasi akan memperoleh kepuasan kerja sebesar 12 kali lebih tinggi dibandingkan perawat yang tidak mendapatkan motivasi dari manajer keperawatan setelah dikontrol variabel kebijakan.

Sementara itu, hasil analisis didapatkan $O d d s$ Rotio (OR) dari variabel kebijakan adalah 2, 436 artinya perawat pelaksana yang mempunyai persepsi dan sikap baik tentang kebijakan akan memperoleh kepuasan kerja sebesar 2 kali lebih tinggi dibandingkan perawat yang tidak mempunyai persepsi dan sikap baik tentang kebijakan setelah dikontrol variabel motivasi. Nilai $p$ variabel motivasi adalah 0,000 artinya dengan $\alpha=0,05$, maka motivasi dapat menentukan kepuasan kerja perawat pelaksana.

Tabel 5.12

Hasil analisis seleksi multivariat variabel kebijakan dan motivasi dengan kepuasan kerja perawat pelaksana di salah satu RSUD di Jawa Timur, Juni 2007 (n=146)

\begin{tabular}{lcccccc}
\hline Variabel & B & S.E & Wald & df & Sig. & $\operatorname{Exp~(B)~}$ \\
\hline Kebijakan & 0.890 & 0,373 & 5,687 & 1 & 0,017 & 2,436 \\
Motivasi & 2,459 & 0,651 & 14,248 & 1 & 0,000 & 11,688 \\
\hline
\end{tabular}

\section{PEMBAHASAN}

Hasil penelitian didapatkan persepsi perawat tentang: 1) tambahan uang lembur $(83,6) ; 2)$ tunjangan insentif disesuaikan dengan jumlah klien $(83,1) ; 3)$ transparansi penghitungan insentif $(78,3)$;
4) transparansi pendapatan insentif $(73,3)$; serta 5) insentif perawat senior sama $(67,0)$.

Terkait dengan imbalan jasa, hal yang perlu diperhatikan oleh manajer keperawatan dan jajaran direksi di salah satu RSUD di Jawa Timur adalah: 1). transparansi dalam mekanisme pembagian dan penetapan indeks, 2). waktu pembayaran yang jelas, 3). prinsip keadilan., 4). Evaluasi berkala dalam pembagian jasa pelayanan, dan 5) melibatkan manajer keperawatan dalam menetapkan kebijakan.

Pelatihan dapat digunakan untuk memperluas pengetahuan, meningkatkan ketrampilan, dan menyiapkan perawat untuk dapat memberikan pelayanan keperawatan yang berkualitas. Sementara itu, seiring dengan perkembangan dan kompetisi yang menuntut pelayanan yang lebih baik, maka karyawan membutuhkan pelatihan agar dapat mengimbangi persaingan(Dessler, 2004).

Rotasi perawat pelaksana di salah satu RSUD di Jawa Timur pernah menjadi masalah yang membutuhkan perhatian ekstra dibandingkan dengan imbalan jasa dan pengembangan staf, dan ternyata berdasarkan hasil penelitian ditemukan sebanyak 82 perawat dari 146 perawat $(56,2 \%)$ mempunyai persepsi dan sikap yang tidak baik tentang rotasi.

Karyawan yang mempersepsikan bahwa kebijakan dibuat secara adil (fair and just) akan mempengaruhi kepuasan kerja (Robbin, 2003). Apabila tindakan yang dilakukan oleh karyawan untuk mengembalikan keadilan tidak berhasil dan karyawan tetap diperlakukan tidak adil, maka karyawan mengambil tindakan mengundurkan diri.

Adapula karyawan yang tetap bergabung dengan perusahaan dan menerima keadaan tersebut, tetapi melakukan tindakan negatif untuk membalas perlakuan perusahaan. Hal lain yang akan dilakukan karyawan adalah mengadukan rasa ketidakadilan tersebut kepada pihak internal atau eksternal dari perusahaan (Lee, 2000 dalam Yulianto 2005).

Kejadian yang terkait rotasi perawat pelaksana di salah satu RSUD di Jawa Timur adalah perawat tetap bertahan sebagai karyawan dan mengadukan ketidakadilan terkait dengan kebijakan rotasi kepada Badan Kepegawaian Daerah (BKD) Kabupaten Ponorogo Jawa Timur, yang merupakan pihak eksternal. 
Perawat pelaksana juga mengungkapkan rasa tidak adil terhadap sistem rotasi tersebut dengan pihak internal yaitu jajaran direksi rumah sakit. Adanya sikap dan persepsi perawat pelaksana di RSUD Jawa Timur tentang kebijakan yang tidak baik $(54,8 \%)$, maka perlu adanya pelatihan pada karyawan tetap tentang regulasi maupun kebijakan yang berlaku dalam organisasi. Kegiatan ini perlu dilakukan karena karyawan diharuskan mengetahui regulasi maupun kebijakan yang berlaku, dengan pelatihan akan ada share value dan kesatuan pandangan (Weaver \& Trevino, 2001 dalam Sumarsono, 2006).

Dalam rangka optimalisasi supervisor yang telah ada, maka supervisi dilakukan secara obyektif dan harus mampu melaksanakan self evaluation, progressif, inovatif, dan fleksibel. Selain itu kegiatan supervisi diharapkan dapat mengembangkan kelebihan masing-masing staf dan pelaksana perawatan, konstruktif dan kreatif dalam mengembangkan diri disesuaikan dengan kebutuhan dan dapat meningkatkan kinerja bawahan dalam upaya meningkatkan kualitas asuhan keperawatan (Saljan, 2005).

Odds Rotio (OR) dari variabel motivasi adalah 11,668 , artinya perawat pelaksana yang mendapatkan motivasi akan memperoleh kepuasan kerja 12 kali lebih tinggi dibandingkan perawat yang tidak mendapatkan motivasi dari manajer keperawatan setelah dikontrol variabel kebijakan $(\mathrm{p}=$ $0,000, \alpha=0,05)$.

Memotivasi bawahan berarti menjadikan mereka merasa bekerja sebagai bagian hidup yang harus dinikmati. Simanjuntak (2005), menjelaskan cara membangun motivasi dalam lingkungan kerja meliputi: 1). merasa diperlukan oleh organisasi; 2) mengetahui yang diharapkan karyawan dan individu; 3) perlakuan adil antar pekerja dan pemberian imbalan; 5) peluang untuk berkembang; 6) tantangan yang menarik; 7) suasana kerja yang menyenangkan.

Tiga variabel (kebijakan, supervisi, motivasi) hanya sebagian kecil faktor yang mempengaruhi kepuasan kerja. Banyak faktor lain yang mempengaruhi kepuasan kerja, sehingga perlu diketahui faktor lain yang mempengaruhi kepuasan kerja perawat termasuk faktor internal perawat antara lain umur, lama kerja, beban keluarga (jumlah anak), dan status kepegawaian.

\section{KESIMPULAN}

Sebagian besar $(54,8 \%)$ perawat mempunyai persepsi tidak baik tentang kebijakan (imbalan jasa, pengembangan staf, dan rotasi. Sebagian besar $(52,1 \%)$ perawat pelaksana mempunyai persepsi tidak baik tentang pelaksanaan supervisi, 55,5\% perawat mempunyai persepsi baik tentang pemberian motivasi oleh manajer keperawatan, $54,8 \%$ perawat merasakan puas terhadap pekerjaannya di RSUD Jawa Timur. Variabel yang paling berhubungan dengan kepuasan kerja perawat pelaksana adalah motivasi yang berasal dari manajer keperawatan $(\mathrm{p}=0,000, \mathrm{OR}=11,668)$.

Berdasarkan simpulan, maka saran peneliti adalah diadakan sosialisasi apabila akan diterapkan atau ada perubahan kebijakan yang menyangkut perawat pelaksana. Sosialisasi kebijakan dapat melalui kepala ruang atau surat yang diedarkan pada semua ruangan, memberikan penghargaan kepada perawat yang berprestasi dalam bentuk uang dan piagam penghargaan, sehingga perlu diadakan pemilihan perawat berprestasi setiap ulang tahun rumah sakit atau peringatan hari ulang tahun PPNI.

Selain itu perlu mengidentifikasi kebutuhan tentang pengembangan staf dan penambahan pengembangan staf melalui pendidikan formal (jenjang pendidikan), pendidikan berkelanjutan, dan pelatihan dalam meningkatkan mutu pelayanan keperawatan yang bermasalah.

Disamping itu perlu penjelasan kembali mengenai aturan yang telah disepakati, dan memberikan kesempatan kepada yang bersangkutan untuk memperbaiki diri. Apabila perawat terpaksa dirotasi, maka jangan sampai menimbulkan persepsi bahwa rotasi sebagai bentuk hukuman, namun sebagai upaya penambahan pengalaman.

Dalam kegiatan rotasi, hendaknya didasarkan pada kinerja, prestasi, dan masa kerja. Rotasi dilakukan secara rutin dan dibentuk tim, sehingga saat keputusan rotasi ditetapkan tidak akan menimbulkan asumsi yang negatif dari perawat yang dirotasi.

Memberikan penyegaran atau pelatihan kepada kepala ruang tentang supervisi. Seorang manajer diharapkan bisa "ing ngarso sung tulodho, ing madya mangun karsa, tut wuri handayani”. 
Pepatah ini dipopulerkan oleh Ki Hajar Dewantoro Artinya manajer keperawatan saat didepan jadi tauladan atau contoh, ditengah memberi motivasi kepada kepada bawahan untuk mengembangkan kreatifitas, dan dibelakang memberikan dukungan dan semangat kepada perawat pelaksana untuk terus meningkatkan kemampuan diri (MS, HH, KN).

* Staf Akademik AKPER Pemerintah Kabupaten Ponorogo, Jawa Timur

** Staf Akademik Kelompok Kelimuan Dasar Keperawatan dan Keperawatan Dasar FIK UI, Depok

***Staf Akademik Departemen Pendidikan Kesehatan dan Ilmu Perilaku FKM UI, Depok

\section{KEPUSTAKAAN}

Asnawi. (2000). Aplikasi psikologi dalam manajemen sumber daya manusia (Cetakan I). Jakarta: Pusgrafin.

Azwar, A. (1996). Pengantar administrasi kesehatan. Jakarta: Binarupa Aksara.

Debora. (2007). Pengaruh prmberdayaan kerja dan psikologis terhadap kepercayaan organisasional dan kepuasan kerja dosen tetap perguruan tinggi swasta. Diperoleh dari http://www.petra.ac.id/puslit/journals/ dir.php?DepartemenID=MAN.

Ellis, J.R., \& Hartley, C.L. (2000). Managing and coordinating nursing care (2nd ed). Philadelphia: W.B. Saunders Company.

Gillies, D.A. (1994). Nursing management, system approach. Chicago: Lippincott Company.

Hansten, R.I., \& Washbun, M.J. (2001). Kecakapan pendelegasian klinis, pedoman untuk perawat. Jakarta: EGC.

Huber, D. (2000). Leadership and nursing care management (2nd ed). Philadelphia: W.B. saunders Company.

Maridi. (2006). Hubungan lingkungan kerja dan iklim organisasi dengan kepuasan kerja perawat di Rumah Sakit Islam Jakarta Pondok Kopi (Tesis, tidak dipublikasikan). Program Pascasarjana Fakultas Ilmu Keperawatan Universitas Indonesia.

Marquis, B.L., \& Houston, C. J. (2003). Leadership roles and management function in nursing, Theory and application (4rd ed). Philadelpia: Lippincott.

Nilvia, (2006). Identifikasi faktor-faktor kepuasan kerja terhadap kinerja karyawan. Diperoleh dari http://diglib.itb.ac.id/gdl.php?

Nursalam. (2002). Manajemen keperawatan, aplikasi dalam praktik keperawatan. Jakarta: Salemba Medika.

Robbin, S. (2003). Perilaku organisasi (Edisi Indonesia). Jakarta: Indeks kelompok Gramedia.

Saljan, M. (2006). Pengaruh pelatihan supervisi terhadap peningkatan kinerja perawat pelaksana di Rumah Sakit Islam Jakarta Pondok Kopi (Tesis, tidak dipublikasikan). Program Pascasarjana Fakultas Ilmu Keperawatan Universitas Indonesia.

Siregar, D.D. (2006). Kepuasan kerja dan produktivitas. Diperoleh dari http://www./ ppm.ac.id/index,php.

Sumarsono, H. (2006). Program etika: Peran dan fungsi manajemen sumber daya manusia.. Jurnal Ilmiah ilmu sosial-humaniora, 3 (2), Juli 2006. Ponorogo: Universitas Muhammadiyah.

Swansburg, R.C. (1995). Nursing staff development. Boston: Jones and Barlett Publisher.

Wardhono. (2004). Tameng sekaligus senjata hadapi AFTA (Diskusi panel, makalah tidak dipublikasikan). Jakarta: Majelis Nasional KAHMI.

Yulianto, H. (2005). Analisis pengaruh distributive justice terhadap turnover intention dengan kepuasan kerja sebagai variabel premediasi. Jurnal ilmiah ilmu sosial-humaniora, 2 (2), Juli 2005. Ponorogo: Universitas Muhammadiyah. 